\section{France seeks policy in haste}

BRITAIN'S reaction to the ethical and legal questions surrounding in vitro fertilization, embryo research, the donorship of sperm and ova and surrogate motherhood has been a rush to legislate - with or without the advice of expert committees. In France, the approach, on the face of it, has been the opposite - to think first, to continue thinking and to leave the legislation until later.

But time is not on the French side. Quite apart from the rate of development and application of the science, France will be taking the lead in a debate later this year in the Council of Europe on legislative problems raised by the new techniques. So the French justice ministry is hastily trying to get its legal minds into some kind of order, leaving the deliberations of the French local and national ethical committees, which are attached to the ministry of health, to one side, of fended by justice minister Robert Badinter's haste. The result is a muddle almost equal to that in Britain.

But the French political philosophy, at least, is clear enough. According to President François Mitterrand, "everything that touches life itself concerns each one of us, and nobody can decide $a$ priori what is good or bad for his neighbour".

Thus, Mitterrand says, there should be no attempt to leave the judgements to "experts", as Britain has tried to do, perhaps unsuccessfully, with its committee on the issues chaired by a philosopher (Baroness Warnock). Rather, in France, Mitterrand wishes to see a wide public debate and public consensus before decisions are taken.

Indeed, Mitterrand even sees France, with its logical, philosophical and evolutionary history, as the place where these issues might first be democratically resolved. "In these domains", Mitterrand said at a conference held by Badinter last month, "France could play again the role it played at the end of the eighteenth century, when it was necessary to invent liberty and democracy."

All very well, but so far the French debate has been, in practice, heavily controlled, and experts have been well in evidence. The "national ethical committee", established by the medical research council INSERM (although now under the ministry of health) under the chairmanship of ex-president of the academy Professor Jean Bernard, held its first "public debate" on the issues last December. But Bernard is said to have dominated the meeting, and simply attempted to assure the public that all was well and that the scientists knew what they were doing.

Moreover, earlier last year, the committee had issued guidelines for embryo research that legal opinion now

\section{Biotechnology}

considers useless. According to the committee, the use of embryos was legitimate if the ends were "therapeutic, diagnostic or scientific", but "the embryo must be recognized as a potential human being which is or has been living and which must be respected in everything".

These statements are contradictory, in the opinion of a leading professor of law, Michelle Gobert of the University of Paris II, who therefore considers that the national committee "has resolved nothing in the present state of French law". On other issues, French law is equally at sea. In the case of surrogate motherhood, for example, the legitimate father will be the husband of the surrogate mother, as French law generally assumes the husband of a pregnant woman to be the father, and he will have to disavow the child under Article 312 of the Civil Code if another man, such

\title{
US speeds scrutiny and consent
}

\section{Washington}

AFTER a shaky start, the US Patent and Trademark Office is moving quickly to answer longstanding complaints of inconsistent and at times incompetent handling of biotechnology patent applications. The patent office plans almost to double its number of biotechnology patent examiners by the end of the year, with the aim of reducing the backlog of more than 2,600 pending applications and cutting the processing time from 28 to 18 months.

The patent office made a major change last year in the way it handles biotechnology patents when it consolidated its biotechnology examiners into a single section. Previously, a patent might go to the organic chemistry group if it was considered to deal mainly with nucleotides, to the polymer group if it was judged to be about peptides or to a third group if was about fermentation products. These groups have now all been incorporated into group 120, which covers pharmaceuticals generally. Group 120 is now receiving virtually all applications involving genetic engineering and 90 per cent of the applications dealing with any aspect of what can be broadly defined as biotechnology. The number of biotechnology patent examiners will increase from 26 now to 40 by the end of the year. The number within that total dealing with genetic engineering will rise from 15 or so at present to 20 .

Rene Tegtmeyer, assistant commissioner for patents, acknowledges the criticism that many of the older senior examiners who handled the first biotechnology applications did not know the technology. But Tegtmeyer claims that the problem is being solved by bringing in new blood, increasing in-house training programmes and as the genetic father, is to claim parenthood.

In such ways, then, French law is in no better state than that of other countries. And the debate, so far, is not much more advanced. This was perhaps why Badinter's colloquium on "Genetics, procreation and the law" last month brought together many experts in law, medicine, sociology, psychiatry and biology to present papers Badinter and his colleagues wished to "bone up" on the issues. The setting of Badinter's meeting was, however, formal - and again there was little debate. Thus Mitterrand's ideal has yet to be realized in France.

The practical question now must be more mundane: will the ministry of health (to which Jean Bernard's national ethical committee reports) or Badinter's justice ministry (which must make the presentation to the Council of Europe) take the lead in what seems more and more likely to be just a hidden French version of "expert advice"?

Robert Walgate improving the patent office's information resources. These now include all commercial databases as well as Georgetown University's semi-private database.

Patent attorneys practising in the biotechnology areas agree that these are steps in the right direction. But one leading genetic engineering patent attorney notes that inconsistencies persist because of the gulf between the senior examiners, who are well versed in patent law and patent-office procedures but deficient in technical expertise, and the newly hired examiners who understand the science but not the law.

The inconsistencies have highlighted two major issues - the scope of and the disclosure requirements for patents. At the outset, the patent office was approving very broad patents in genetic engineering, of which the best known is the Cohen-Boyer patent covering the basic procedure for inserting foreign DNA into a bacterium using a plasmid vector. The patent office is now, patent attorneys say, going to the other extreme, and rejecting many broad claims. The attorneys say it will be some time before a proper balance is attained.

The issue of disclosure requirements has likewise swung to and fro. Some applications have been approved without the applicant having made a deposit of key starting material in a publicly accessible culture depository, such as the American Type Culture Collection. More recently, others have been rejected on these grounds. Several cases now pending before the board of patent appeals may settle this issue.

Despite the complaints, the US patent office appears to be well ahead of both Japan and Europe in dealing with the flood of new biotechnology applications.

Stephen Budiansky 